\title{
USE OF GEOGRAPHIC INFORMATION SYSTEM AND WATER QUALITY INDEX TO ASSESS SUITABILITY OF GROUNDWATER QUALITY FOR DRINKING PURPOSES IN HEWANE AREAS, TIGRAY, NORTHERN ETHIOPIA
}

${ }^{*}$ Abraham Bairu, ${ }^{1}$ Nata Tadesse ${ }^{2}$ and Sahleselassie Amare ${ }^{3}$

\author{
http://dx.doi.org/10.4314/ejesm.v6i2.1
}

Received 20th February 2012; accepted 15th February 2013

\begin{abstract}
The study area Hewane is situated in the southern zone of Tigray Regional State, Hintalo Wajirat wereda. It is geographically located between 1444000 to $1454000 \mathrm{~m} \mathrm{~N}$ and 550000 to $558000 \mathrm{~m}$ E with an aerial extent of $47.66 \mathrm{sq} . \mathrm{km}$. The study was conducted having an objective of assessing suitability of groundwater quality for drinking purposes through geographic information system (GIS) and water quality index (WQI). Ten groundwater samples were collected from the study area and 13 physicochemical parameters such as TDS, $\mathrm{TH}$, Alkalinity, $\mathrm{pH}, \mathrm{EC}$, Temperature, $\mathrm{Na}^{+}, \mathrm{K}^{+}, \mathrm{Mg}^{2+}, \mathrm{Ca}^{2+}, \mathrm{Cl}^{2}, \mathrm{HCO}_{3}^{-}$and $\mathrm{SO}_{4}{ }^{2-}$ were analyzed. Inverse distance weighted (IDW) interpolation method has been used to generate the spatial distribution of the groundwater physico-chemical parameters and water quality index map. To estimate the water quality index, 9 parameters have been considered: $\mathrm{pH}, \mathrm{Na}^{+}, \mathrm{K}^{+}, \mathrm{Mg}^{2+}, \mathrm{Ca}^{2+}, \mathrm{Cl}$, $\mathrm{HCO}_{3}{ }_{3}, \mathrm{SO}_{4}{ }^{2-}$, and TDS. The WQI estimated for the groundwater samples of the study area ranges from 86.1 to 180.5 at groundwater samples GWS_2 and GWS_5, respectively. Based on the analysis, most of the area under study falls $70 \%$ in poor water class and 30\% in good water class. Hence, the result revealed that $70 \%$ of the groundwater samples of the study area are hardly suitable for drinking purposes without water quality management activities.
\end{abstract}

Key words: spatial distribution, GIS, WQI, groundwater quality, Hewane, Tigray, Ethiopia

\section{Introduction}

Water quality is a term used to describe the chemical, physical and biological characteristics water, usually in respect to its suitability for a particular purpose (Sargaonkar and Deshpande, 2003; Khan et al., 2003). Groundwater has long been regarded as the pure form of water compared to surface water, because of purification of the former in the soil column through anaerobic decomposition, filtration and ion exchange. This is one of the reasons for the excessive consumption of groundwater in rural and semi-urban areas all over the world (Kannan and Joseph, 2009). Groundwater, being a fragile and important source of drinking water, must therefore be carefully managed to maintain its purity within standard limits. Groundwater degradation occurs when its quality parameters are changed beyond their natural variations by the introduction or removal of certain substances (Ramesh, 2001; Todd, 2001).

Geographic information system can be a powerful tool for developing solutions for water resources problems, assessing water quality, flooding, understanding the natural environment and for managing water resources on a local and/or regional scale (Ferry et al., 2003). It is a very powerful tool for processing, analyzing and integrating spatial data sets. In a very comprehensive sense, GIS may mean identifying data needs, acquiring data, data management, processing and analysis of data and decisionmaking.

Chemical quality of groundwater is an important attribute data which controls water use. These data, being spatially different, can be processed and analyzed in the GIS software in a highly efficient manner. The chemical quality of groundwater is expressed in terms of various parameters like Temperature, Total dissolved solids (TDS), Total hardness (TH), Alkalinity, $\mathrm{pH}$, Electrical conductivity (EC), $\mathrm{Na}^{+}, \mathrm{K}^{+}, \mathrm{Mg}^{2+}, \mathrm{Ca}^{2+}$, $\mathrm{Cl}^{-}, \mathrm{HCO}_{3}^{-}, \mathrm{SO}_{4}^{2-}$, etc. In GIS software, each of these parameters can be treated as a data layer.

The data layer can be suitably contrasted, manipulated and displayed as a black-and-white output.

\footnotetext{
${ }^{1}$ Tigray Water Resources Bureau, Mekelle, Tigray, Ethiopia.

${ }^{2}$ Department of Earth Sciences, Mekelle University, Mekelle, Tigray,

Ethiopia.

${ }^{3}$ Scientific Data Management Directorate, Tigray Science and

Technology Agency, Mekelle, Tigray, Ethiopia

*Corresponding author: abrahambairu@ymail.com
} 
For any city, a groundwater quality map is important for drinking purposes and as a precautionary indication of potential environmental health problems (Challerjee et al., 2009). Hence, the study was conducted having an objective of assessing suitability of groundwater quality for drinking purposes through geographic information system (GIS) and water quality index (WQI).

\section{Methodology}

Location The study was carried out in Hewane situated in the southern zone of Tigray Regional State, Hintalo Wajirat wereda. It is geographically located between 1444000 to $1454000 \mathrm{~m} \mathrm{~N}$ and 550000 to $558000 \mathrm{~m} \mathrm{E}$ and covering an area of 47.66 sq. $\mathrm{km}$. The area is surrounded by mountains with streams flowing towards the central parts of the area. The drainage pattern is mainly dense and shows dendritic pattern. The general flow direction of the streams is directed together towards the northwestern part (Figure 1).

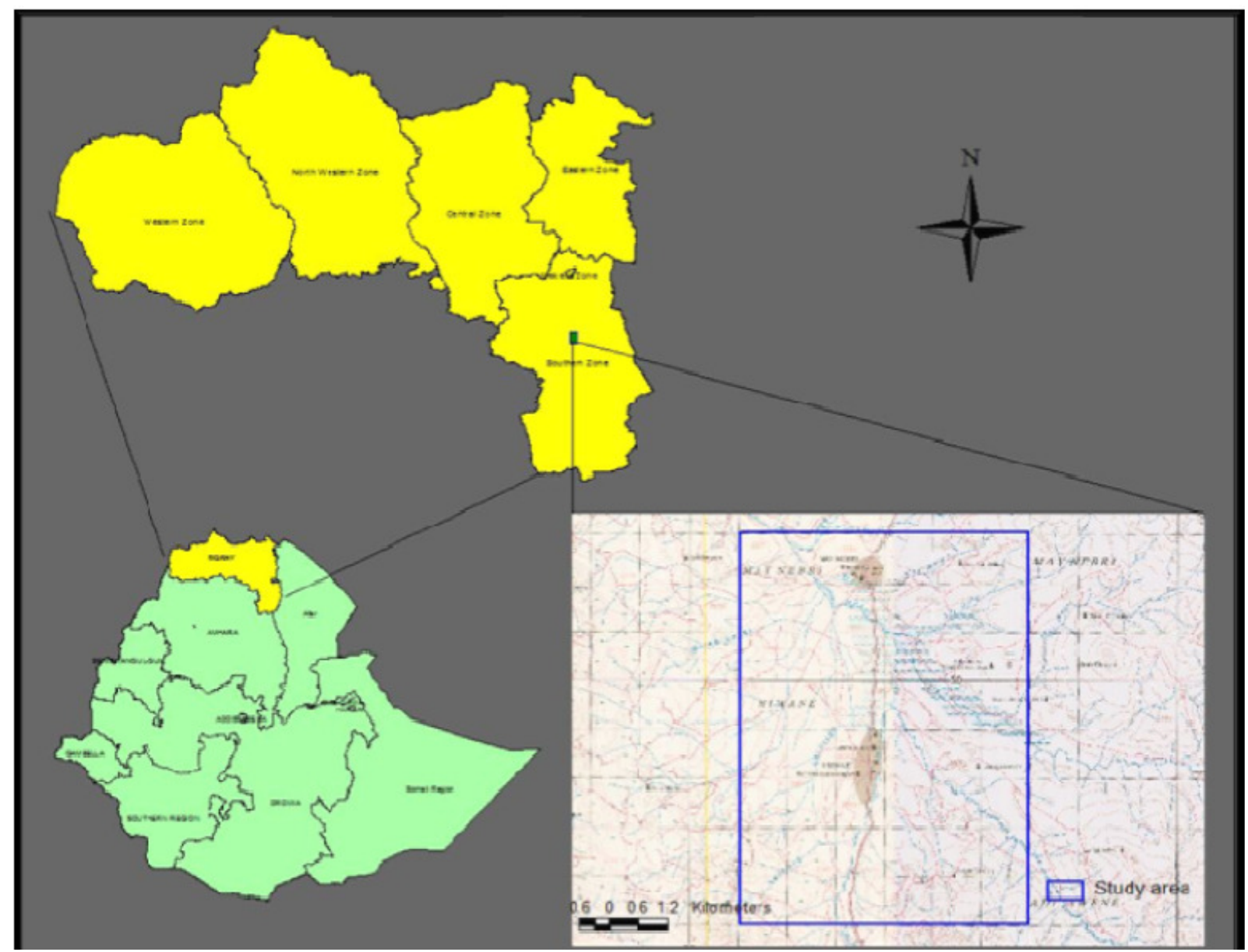

Figure 1 Location map of the study area

\section{Data Collection and Analysis}

Geographic locations, latitude, longitude and elevation of the water points were collected with the help of GARMIN etrex GPS. A total of ten groundwater samples were collected from the study area. All groundwater samples were collected in $2 \mathrm{~L}$ plastic bottles which were washed and triple-rinsed with distilled water and with the water of interest before sampling and transported them to the laboratory. For each groundwater sample a number of physico-chemical parameters like TDS, TH, Alkalinity, $\mathrm{pH}, \mathrm{EC}$, Temperature, $\mathrm{Na}^{+}, \mathrm{K}^{+}, \mathrm{Mg}^{2+}, \mathrm{Ca}^{2+}, \mathrm{Cl}^{2}, \mathrm{HCO}_{3}{ }^{-}$and $\mathrm{SO}_{4}{ }^{2-}$ were analyzed. Temperature, $\mathrm{EC}$ and $\mathrm{pH}$ measurements were taken in-situ using standard equipment (Century Water Analysis Kit). The major cations and anions were analyzed using Atomic 
Adsorption Spectrophotometer (AAS) and Ultra Violet Spectrophotometer (UVS), respectively by Tigray Agricultural and Rural Development Bureau Soil and Groundwater Laboratory as per the standard methods of APHA (2005) and Eaton et al. (1998).

TDS is estimated using the empirical formula after Raghunath (2003).

$\operatorname{TDS}(\mathrm{mg} / \mathrm{l})=0.64 * \mathrm{EC}$

$(\mu \mathrm{S} / \mathrm{cm})$

Total hardness (TH) is estimated using the following formula adopted from Fournier (1981).

Total hardness $(\mathrm{TH})=2.5 \mathrm{Ca}^{2+}+$ 4. $1 \mathrm{Mg}^{2+}$
Where: $\mathrm{TH}, \mathrm{Ca}$ and $\mathrm{Mg}$ are measured in milligrams per liter.

Alkalinity is also calculated from the equilibrium constants for the speciation reaction and the measured $\mathrm{pH}$ of the solution with the following equation (Deutsch, 1997).

Alkalinity $\left(\mathrm{mg} / \mathrm{l} \mathrm{CaCO}{ }_{3}\right)=\left[\mathrm{HCO}_{3}{ }^{-}\right] \mathrm{mg} / \mathrm{l} \times(1+$ $\left.\frac{2 \times 10^{-10.3}}{10^{-\mathrm{pH}}}\right) \times 50 / 61$

Statistical analyses of the physico-chemical parameters was done with the aid of SPSS 15.0 version software package and presented as minimum, maximum, mean, standard deviation and also graphical presentations of physicochemical parameters of the groundwater samples.

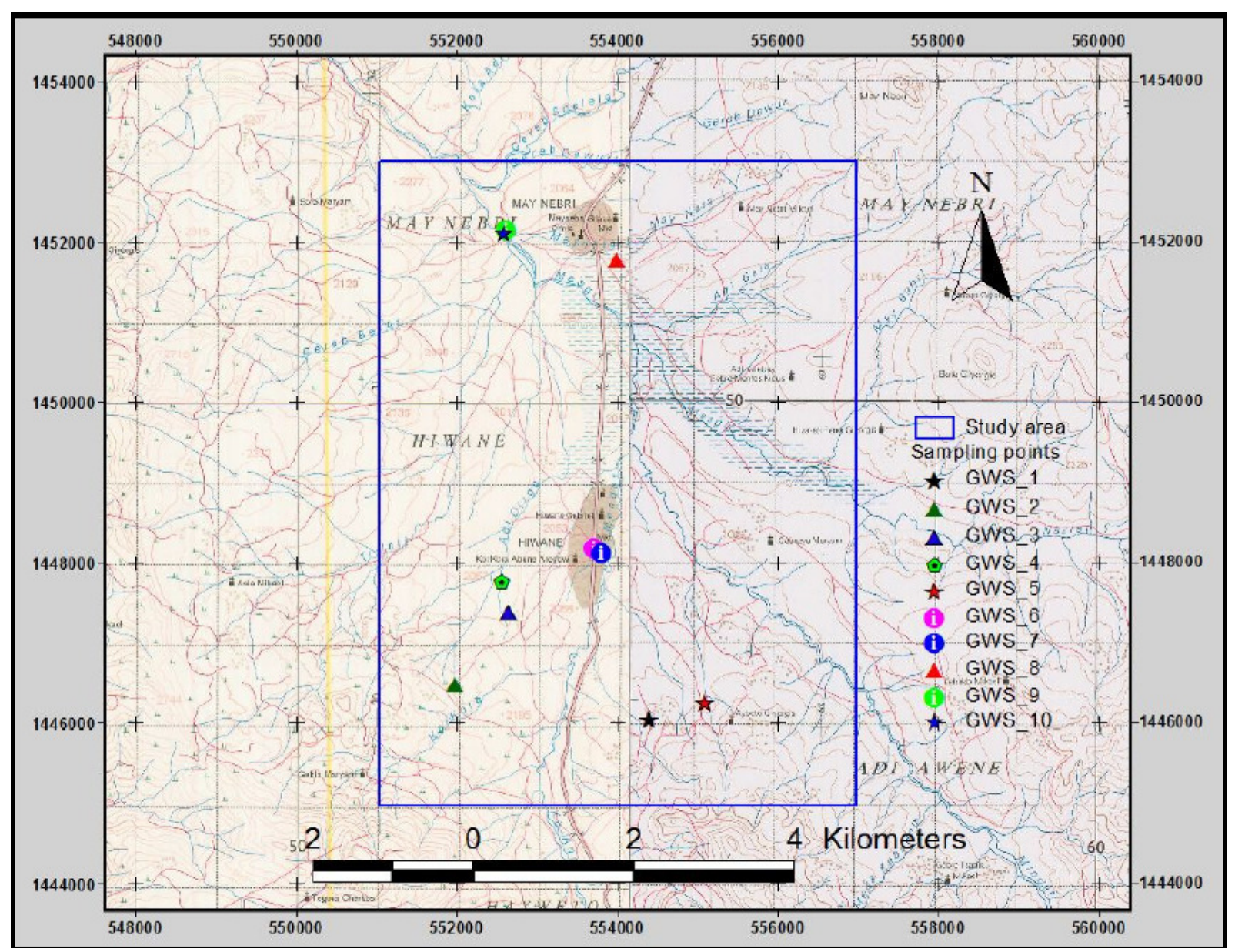

Figure 2 Ground water sampling points map 


\section{Geo-data Preparation and Interpolation}

In the preprocessing phase analyzed groundwater parameters were prepared in a DBF 4 format in the MS Excel Program suitable for exporting into GIS database and make them amendable for integrated analysis.

Keyboard and digitization for entering attribute data of groundwater sample parameters and location data respectively were used to enter the data input into ArcGIS 9.3 software. Once the input data was imported as a point layer, geo-database was created to generate the spatial distribution maps of selected water quality parameters.

Interpolation is the process of predicting unknown values using the known values in the vicinity. For the sake of this research work, pointbased Inverse Distance Weighted (IDW) interpolation method was used to produce spatial distribution thematic maps for each of the groundwater parameters: TDS, TH, Alkalinity, $\mathrm{pH}, \mathrm{EC}, \mathrm{Ca}, \mathrm{Mg}, \mathrm{K}, \mathrm{Na}, \mathrm{Cl}, \mathrm{CHO}_{3}$ and $\mathrm{SO}_{4}$. This interpolation method determines cell values using linearly weighted combination of a set of sample points. The weight is a function of inverse distance. Similarly, Inverse Distance Weighted (IDW) interpolation method was used to produce the WQI map of the study area.

\section{Water Quality Index (WQI)}

Water quality index is computed to reduce the large amount of water quality data to a single numerical value. It reflects the composite influence of different water quality parameters on the overall quality of water. WQI has been computed to determine the suitability of the groundwater for drinking purposes.

\section{Result and Discussion \\ Major Cations and Anions}

The major ions of the groundwater samples in the study area were in the order of $\mathrm{Ca}^{2+}$ $>\mathrm{Mg}^{2+}>\mathrm{Na}^{+}>\mathrm{K}^{+}=\mathrm{HCO}_{3}{ }^{-}>\mathrm{Cl}^{-}>\mathrm{SO}_{4}{ }^{2-}$ while carbonates remain nil throughout the groundwater samples. Calcium is the dominant cation and its concentration ranges from 84.00 to $412.00 \mathrm{mg} / \mathrm{l}$ at groundwater samples GWS_7 to GWS_5 and GWS_10, respectively. Based on Todd (2005), concentration of all groundwater samples were above the maximum permissible limits $(100 \mathrm{mg} / \mathrm{l})$ except 1 groundwater sample, GWS_7 as far as calcium is concerned (Table 1, Figure 3 and 4). Magnesium is the second dominant cation in the study area and its concentration varies from 96.00 to $211.20 \mathrm{mg} / 1$ at GWS_2 and GWS_9, respectively. All the groundwater samples showed a magnesium concentration above the maximum permissible limit $(50 \mathrm{mg} / \mathrm{l})$, Todd (2005) (Table 1 and Figure 3 and 5).

The concentration of sodium ranges between 19.09 and $43.93 \mathrm{mg} / 1$ at GWS_2 to GWS_3 and GWS_9 respectively with an average value of $32.32 \mathrm{mg} / \mathrm{l}$ (Table 1). According to the WHO (2004) guideline, the maximum admissible limit is $200 \mathrm{mg} / \mathrm{l}$. In the study area, all the groundwater samples were found within the maximum permissible limit as far as it is concerned (Figure 3 and 6).

In the study area, the concentration of potassium ranges from 2.34 to $51.09 \mathrm{mg} / \mathrm{l}$ at GWS_1 and GWS_5 respectively with an average value of $18.06 \mathrm{mg} / 1$ (Table 1); and it was found that 4 groundwater samples were having potassium values within the permissible limit and 6 groundwater samples above the permissible limit (10mg/l) (Todd, 2005) (Figure 3 and 7).

Bicarbonate is the dominant anion in the groundwater samples of the study area and its concentration ranges from 244.00 to $585.60 \mathrm{mg} / \mathrm{l}$ at samples GWS_10 and GWS_6, respectively (Table 1). Based on Todd (2005), concentration of all groundwater samples were within the maximum permissible limits $(500 \mathrm{mg} / \mathrm{l})$ except 3 groundwater samples, GWS_1, GWS_6 and GWS_7 as far as bicarbonate is concerned (Figure 3 and 8 ).

Chlorine is the second dominant anion in the study area and its concentration varies from 71.00 to $340.80 \mathrm{mg} / 1$ at GWS_1 and GWS_10 respectively with an average value of $147.68 \mathrm{mg} / 1$ (Table 1). All the groundwater samples showed a chlorine concentration above the maximum permissible limit (10mg/1), Todd (2005) (Figure 3 and 9).

Concentration of sulphate ranges from $49.49 \mathrm{mg} / 1$ in GWS_1 up to $122.5 \mathrm{mg} / \mathrm{l}$ in GWS_8 with an average value of $69.14 \mathrm{mg} / 1$ (Table 1 ). According to the WHO (2004) guideline, the maximum admissible limit is $300 \mathrm{mg} / \mathrm{l}$. Sulphate in all the groundwater samples of the study area were found within the maximum permissible limit as far as it is concerned (Figure 3). The spatial 
distribution of sulphate concentration in groundwater of the study area is illustrated in figure 10. This map shows that all the groundwater samples were within the maximum allowable limit of $200 \mathrm{mg} / 1$.

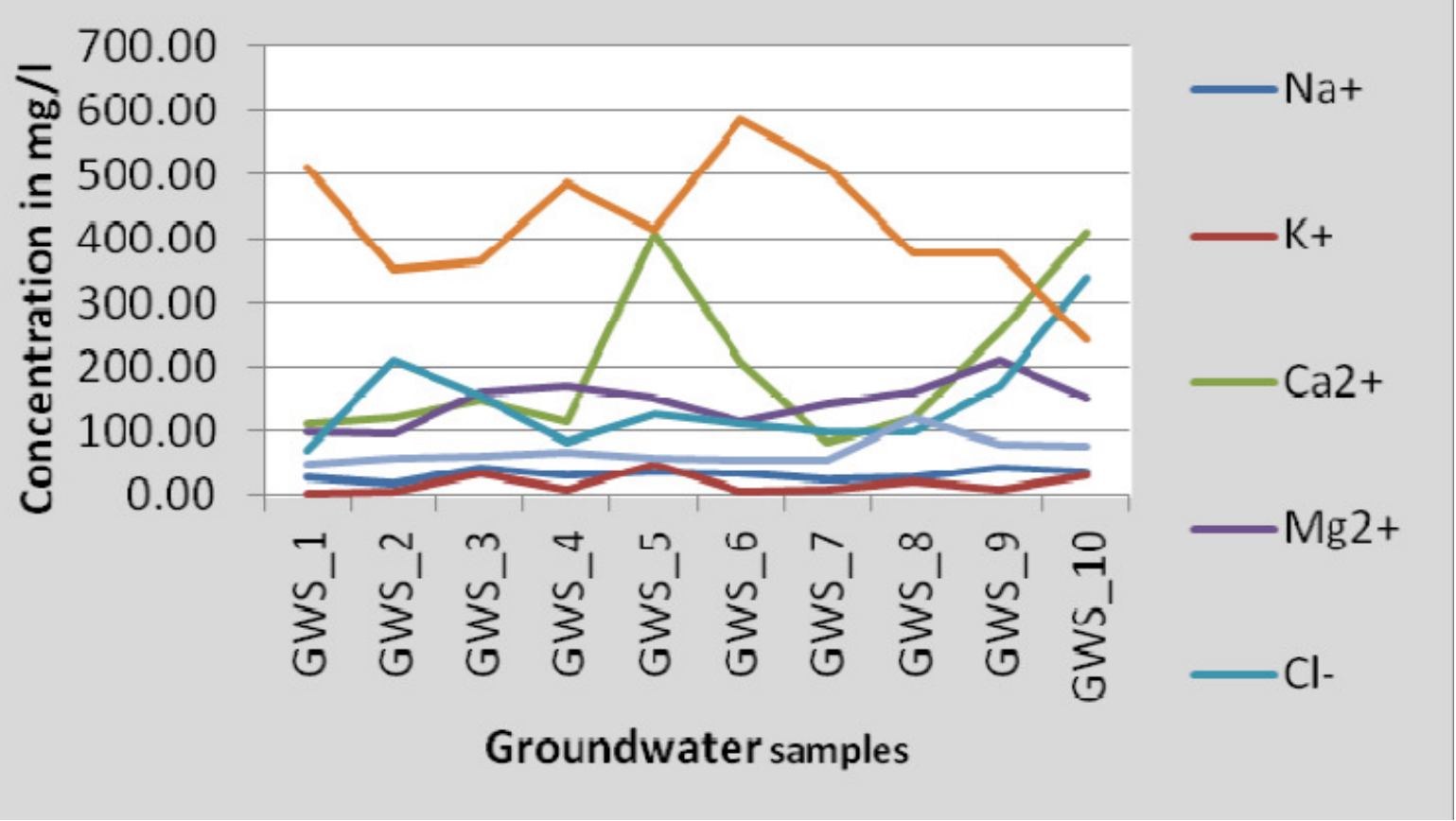

Figure 3 Concentration of major ions in the groundwater samples of Hewane area

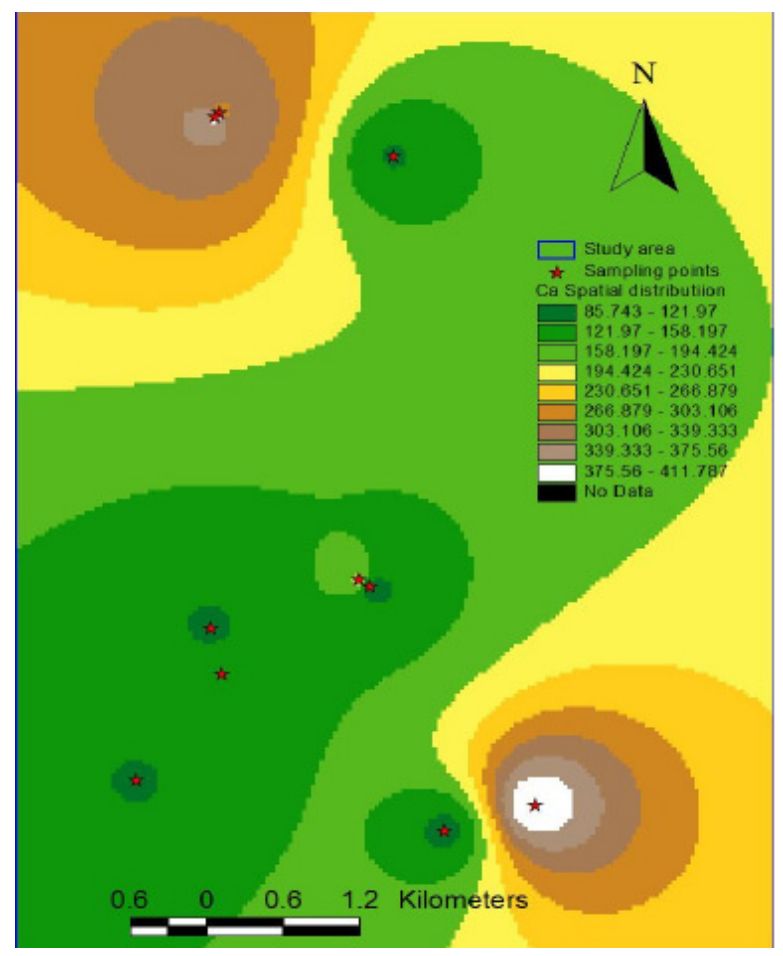

Figure 4 Spatial distribution map of calcium $(\mathrm{mg} / \mathrm{l})$ in Hewane area

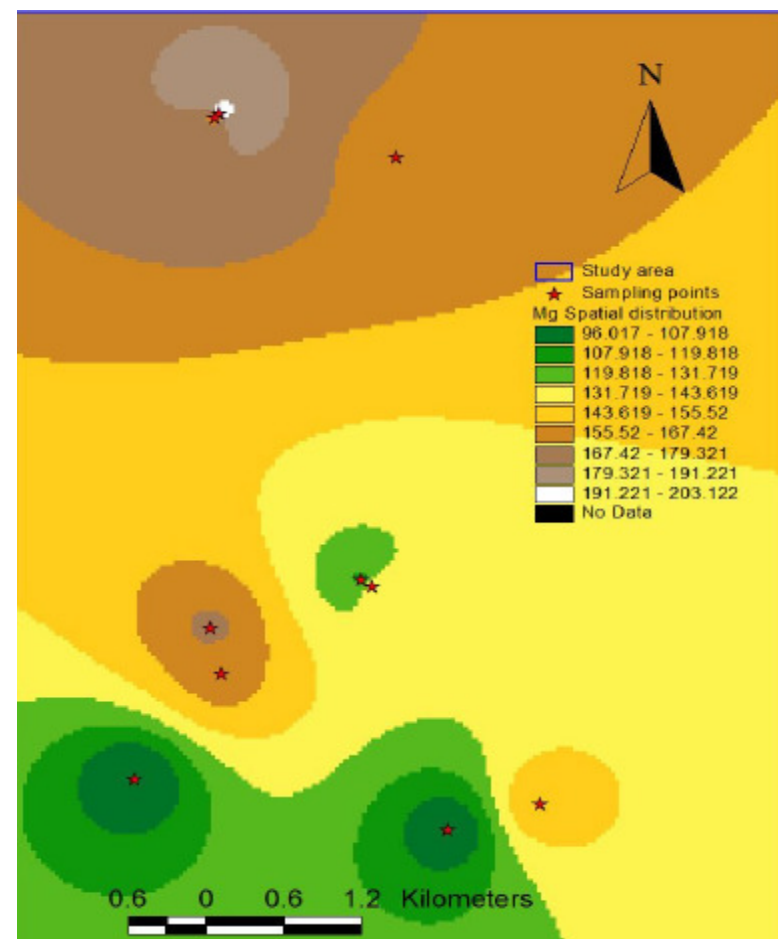

Figure 5 Spatial distribution map of magnesium $(\mathrm{mg} / \mathrm{l})$ in Hewane area 


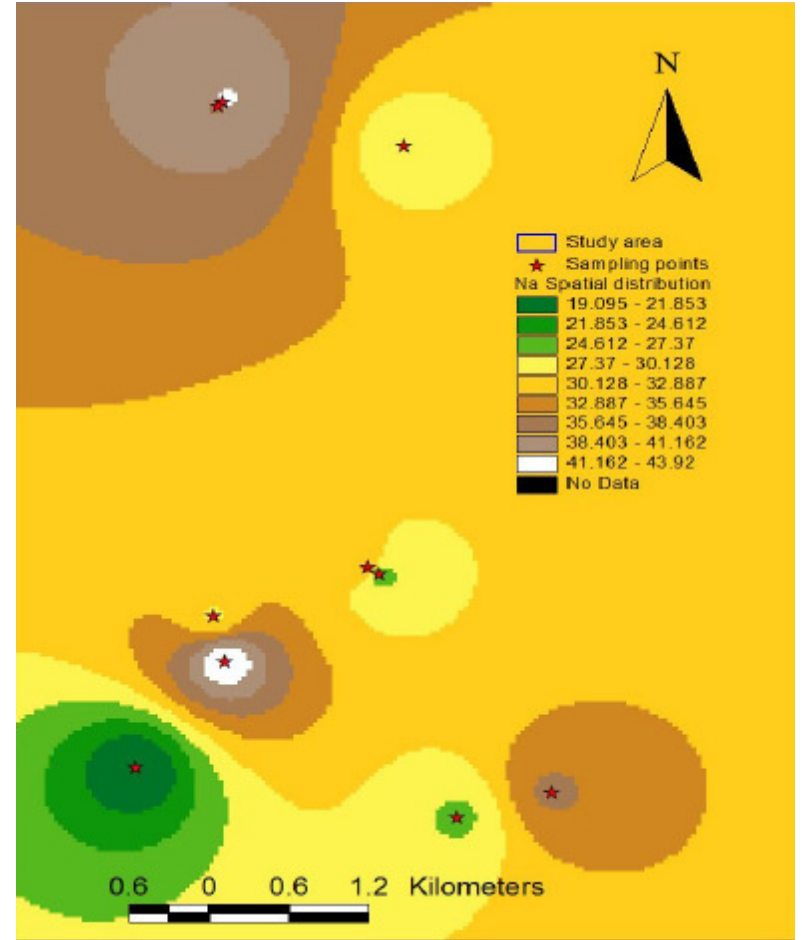

Figure 6 Spatial distribution map of sodium (mg/l) in Hewane area

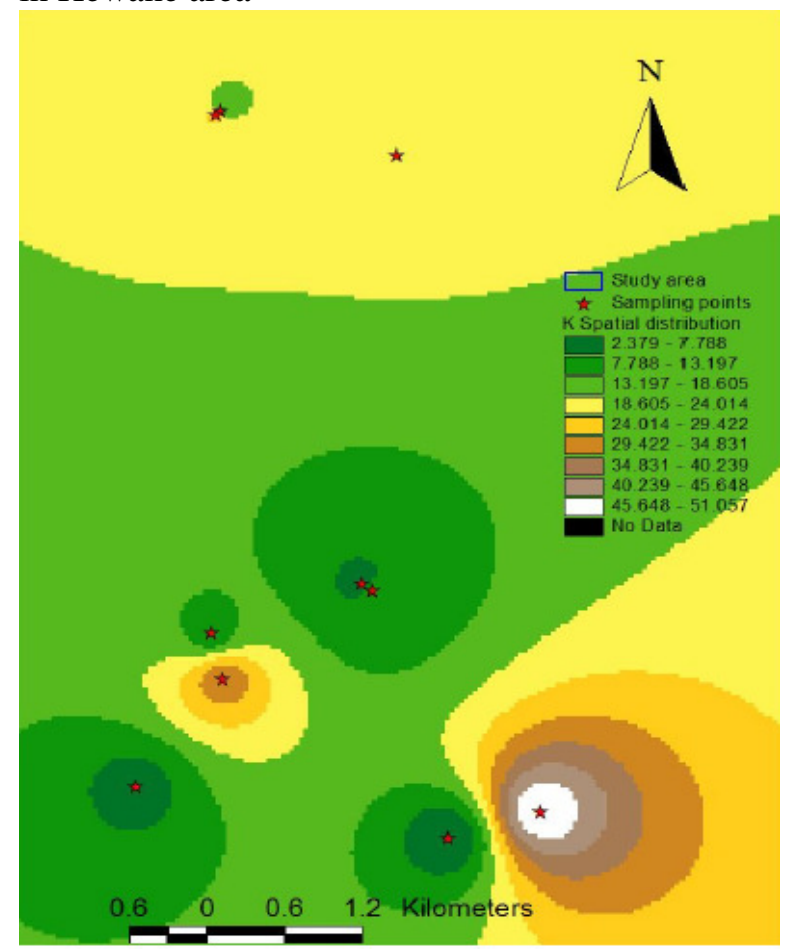

Figure 7 Spatial distribution map of potassium $(\mathrm{mg} / \mathrm{l})$ in Hewane area

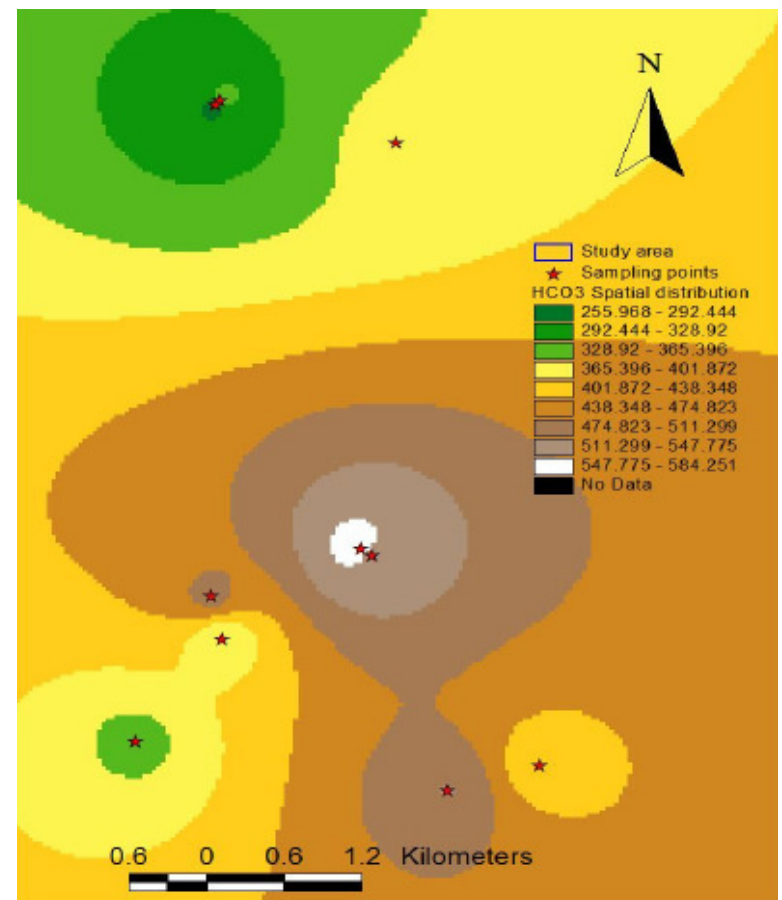

Figure 8 Spatial distribution map of bicarbonate $(\mathrm{mg} / \mathrm{l})$ in Hewane area

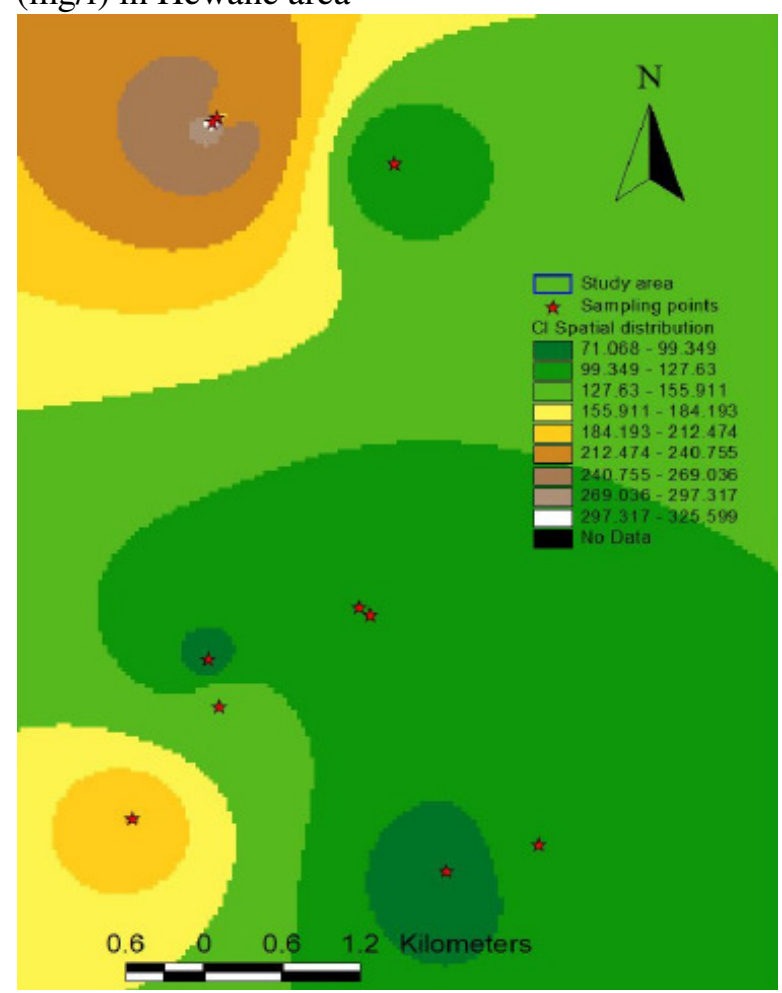

Figure 9 Spatial distribution map of chlorine $(\mathrm{mg} / \mathrm{l})$ in Hewane area 


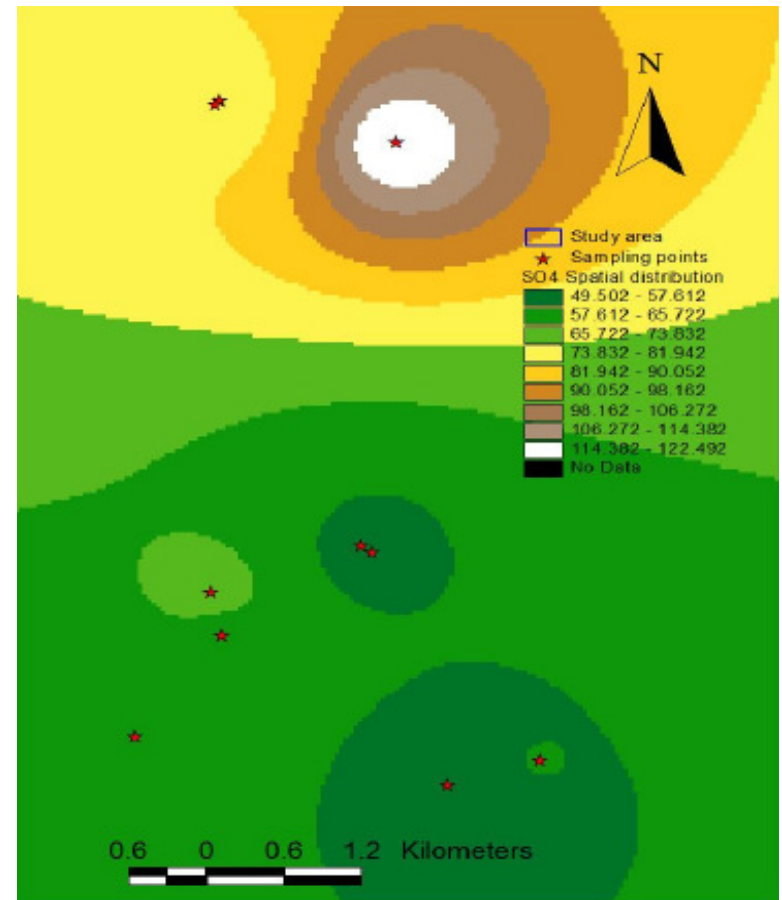

Figure 10 Spatial distribution map of sulphate $(\mathrm{mg} / \mathrm{l})$ in Hewane area

\section{EC and TDS}

$\mathrm{EC}$ of the study area at $25^{\circ} \mathrm{C}$ varies from 0.88 to $3.01 \mathrm{dS} / \mathrm{m}$ at GWS_2 and GWS_5, respectively (Table 1). Hence, according to Driscoll (1986), the EC of 6 groundwater samples were found within the good water class while the remaining 4 groundwater samples were found within the fair water class for the EC between 0.7 $-1.5 \mathrm{dS} / \mathrm{m}$ and $1.5-3.7 \mathrm{dS} / \mathrm{m}$, respectively. The interpreted water quality with respect to $\mathrm{EC}$ indicates that $60 \%$ the groundwater samples of the study area lies in good water class and $40 \%$ lies in fair water class for drinking water purposes. The spatial distribution map EC of the study area is shown in figure 11.

Electrical conductivity of water is considered to be an indication of total dissolved solids (Hem, 1985). Total dissolved solids (TDS) in the study area vary from 564.10 to $1929.48 \mathrm{mg} / \mathrm{l}$ at GWS_2 and GWS_5, respectively (Table 1). Based on the WHO (2004), the groundwater samples are classified in to four categories: 1 groundwater sample is categorized as good $(300-600 \mathrm{mg} / 1), 4$ groundwater samples are fair $(600-900 \mathrm{mg} / \mathrm{l})$ and 1 groundwater sample is poor $(900-1200 \mathrm{mg} / \mathrm{l})$ and the remaining 4 groundwater samples are unacceptable ( $>1200 \mathrm{mg} / \mathrm{l})$. The spatial distribution map of total dissolved solids illustrated in figure
12 shows that the groundwater samples were good, fair, poor and unacceptable.

\section{Total Hardness}

Water hardness is primarily caused by the presence in water of cations such as calcium and magnesium; and of anions such as carbonate, bicarbonate, chloride and sulfate (Ravikumar et $a l ., 2010)$. In the study area total hardness varies from 683.44 to $1768.32 \mathrm{mg} / \mathrm{l}$ of $\mathrm{CaCO}_{3}$ at groundwater samples GWS_1 and GWS_5, respectively (Table 1).

The total hardness of $150-300 \mathrm{mg} / \mathrm{l}$ and above may cause heart diseases and kidney problems (Ramesh and Elango, 2006). All the groundwater samples of the study area exceed $300 \mathrm{mg} / \mathrm{l}$ which is considered to be very hard (Sawyer and McCarty, 1976). The spatial distribution map of total hardness shows that all the groundwater samples $(100 \%)$ falls in the very hard category (Figure 13).

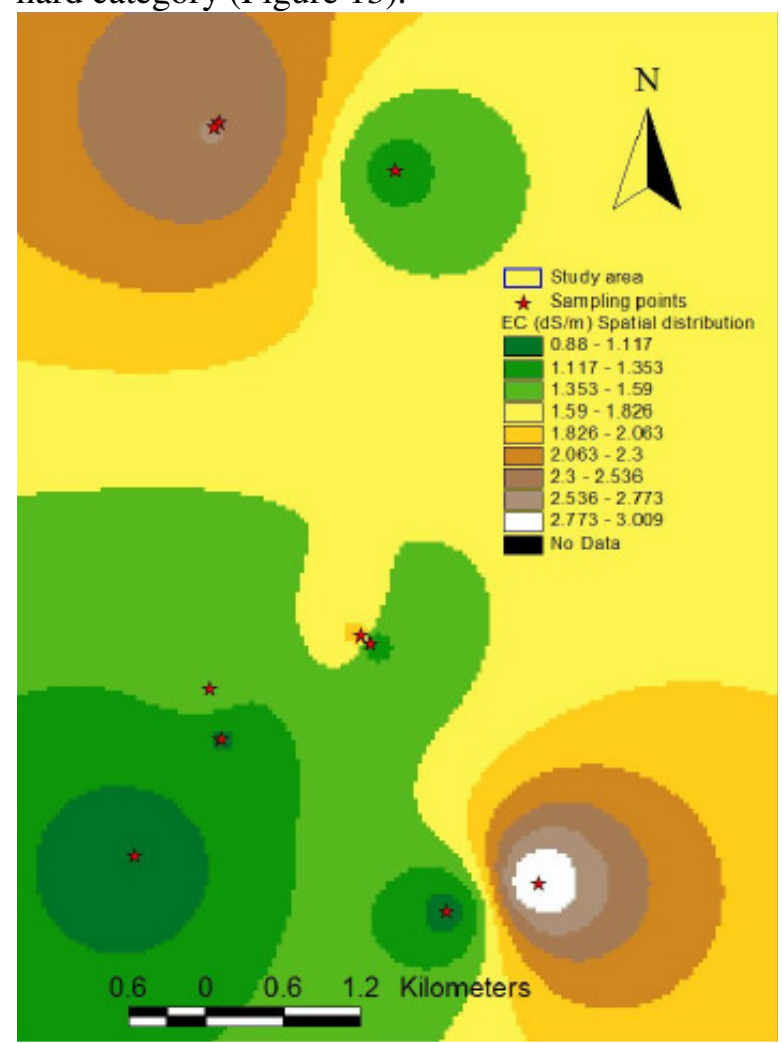

Figure 11 Spatial distribution map of electrical conductivity $(\mathrm{dS} / \mathrm{m})$ in Hewane area

pH

The groundwater of the study area was found basic as its $\mathrm{pH}$ values ranges from 6.84 to 7.43 at groundwater samples GWS_6 and GWS_10, respectively (Table 1). The groundwater samples 
were found within the Secondary Maximum Contaminant Level (SMCL) for $\mathrm{pH}$ is 6.5 to 8.5 on $\mathrm{pH}$ scale as established by the APHA (2005).

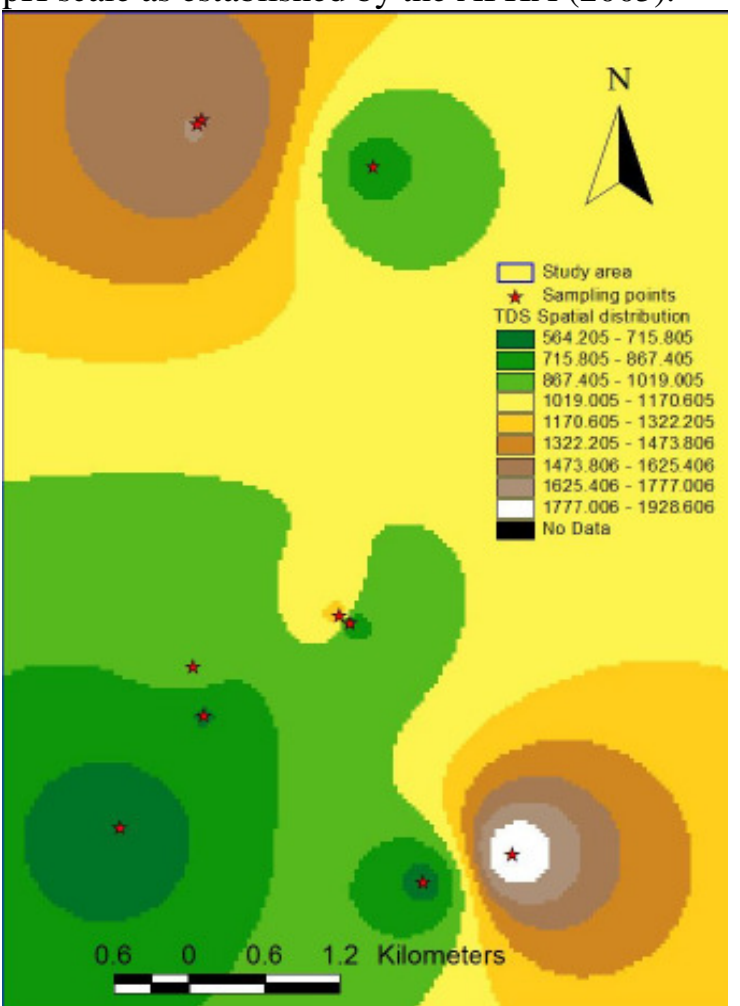

Figure 12 Spatial distribution map of total dissolved solids $(\mathrm{mg} / \mathrm{l})$ in Hewane area

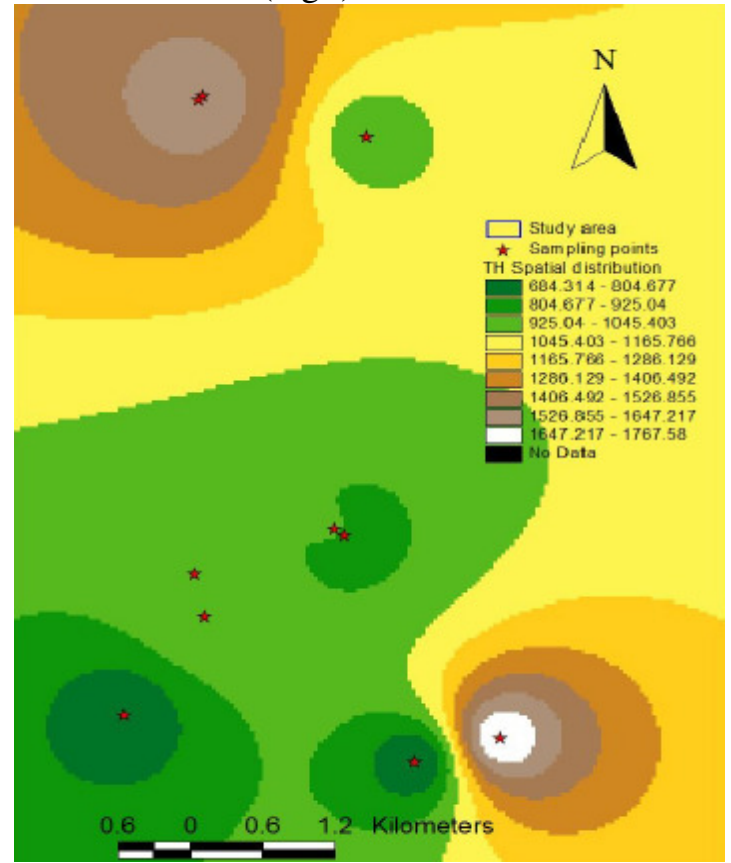

Figure 13 Spatial distribution map of total hardness $\left(\mathrm{mg} / \mathrm{l}\right.$ of $\left.\mathrm{CaCO}_{3}\right)$ in Hewane area
The spatial distribution map of $\mathrm{pH}$ concentrations is shown in figure 14 that all the groundwater samples displayed a $\mathrm{pH}$ value within the maximum permissible limit.

\section{Alkalinity}

Alkalinity was values range from $200.61 \mathrm{mg} / 1$ of $\mathrm{CaCO} 3$ at GWS 10 to $480.12 \mathrm{mg} / \mathrm{l}$ of $\mathrm{CaCO} 3$ at GWS_6 (Table 1). All the groundwater samples of the study area exhibit alkalinity values above the permissible limit of $120 \mathrm{mg} / \mathrm{l}$ (WHO, 2008). The spatial distribution map of alkalinity shows that all the groundwater samples fall above the permissible limit (Figure 15).

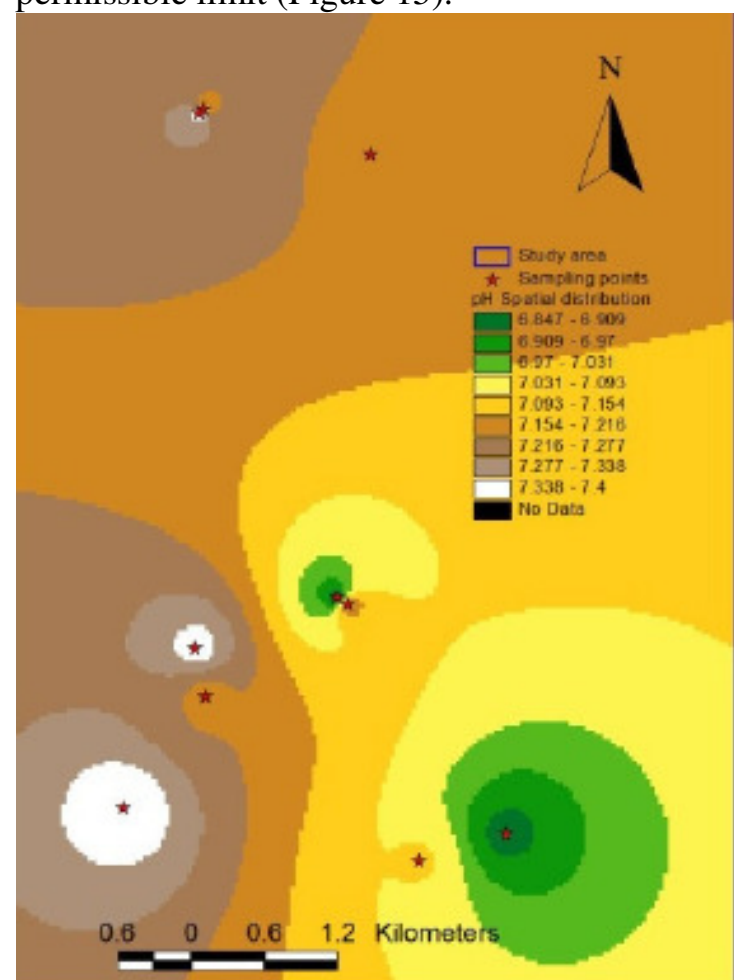

Figure 14 Spatial distribution map of $\mathrm{pH}$ in Hewane area 


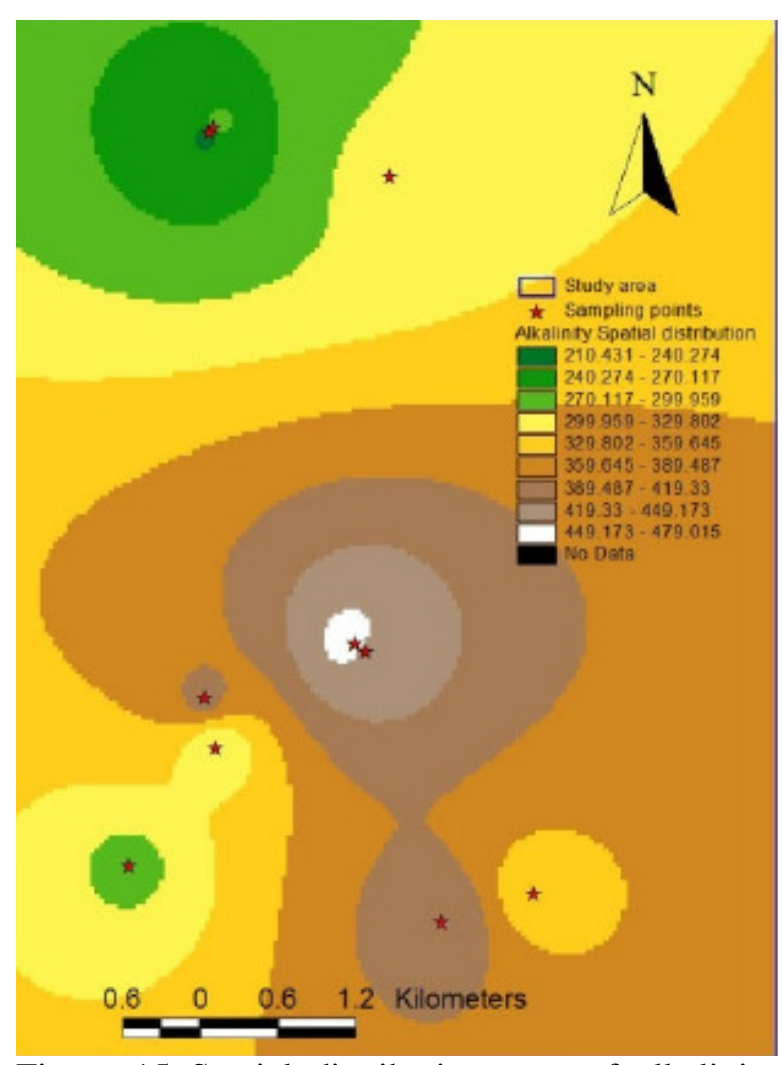

Figure 15 Spatial distribution map of alkalinity $(\mathrm{mg} / \mathrm{l})$ in Hewane area

\section{Calculation of WQI}

The WQI has been calculated to evaluate the suitability of groundwater quality of Hewane areas for drinking purposes. The WHO (2004) standards for drinking purposes have been considered for the calculation of WQI. For the calculation of WQI 9 parameters such as: $\mathrm{pH}$, sodium $\left(\mathrm{Na}^{+}\right)$, potassium $\left(\mathrm{K}^{+}\right)$, magnesium $\left(\mathrm{Mg}^{2+}\right)$, calcium $\left(\mathrm{Ca}^{2+}\right)$, chloride $\left(\mathrm{Cl}^{-}\right)$, bicarbonate $\left(\mathrm{HCO}_{3}^{-}\right)$, sulphate $\left(\mathrm{SO}_{4}{ }^{2-}-\mathrm{S}\right)$, and Total Dissolved Solids (TDS) have been used.

To compute WQI four steps are followed Gebrehiwot et al. (2011). In the first step, each of the 9 parameters has been assigned a weight (wi) according to its relative importance in the overall quality of water for drinking purposes (Table 2). The maximum weight of 5 has been assigned to TDS; weight of 3 has been assigned to parameters $\mathrm{pH}$, chloride, sulphate and sodium; weight of 2 has been assigned to parameters calcium, magnesium, and bicarbonate depending on their importance in the overall quality of water for drinking purposes (Srinivasamoorthy et al., 2008). Potassium is given the minimum weight of 1 as it plays an insignificant role in the water quality assessment.
In the second step, the relative weight (Wi) is computed using a weighted arithmetic index method given below (Brown et al., 1972; Horton, 1965; Tiwari and Manzoor, 1988) in the following steps.

$$
\mathrm{W}_{\mathrm{i}}=\frac{\mathrm{w}_{\mathrm{i}}}{\sum_{\mathrm{i}=1}^{\mathrm{n}} \mathrm{w}_{\mathrm{i}}}
$$

Where, Wi is the relative weight, wi is the weight of each parameter and $n$ is the number of parameters.

In the third step, a quality rating scale (Qi) for each parameter is assigned by dividing its concentration in each water sample by its respective standard according to the guidelines of WHO (2004) and then multiplied by 100 :

$\mathrm{Qi}=(\mathrm{Ci} / \mathrm{Si}) \times 100$.

where Qi is the quality rating, $\mathrm{Ci}$ is the concentration of each chemical parameter in each water sample in $\mathrm{mg} / \mathrm{l}$, and $\mathrm{Si}$ is the WHO drinking water standard for each chemical parameter in $\mathrm{mg} / \mathrm{l}$ according to the guidelines of WHO (2004) (Table 3).

In the fourth step, the SI is first determined for each chemical parameter, which is then used to determine the WQI as per the following equation:

SIi $=$ Wi $\times$ Qi

SIi is the sub index of ith parameter and Qi is the rating based on concentration of ith parameter.

The overall Water Quality Index (WQI) was calculated by adding together each sub index values of each groundwater samples as follows:

$\mathrm{WQI}=\sum \mathrm{SIi}$.

Computed WQI values are usually classified into five categories (Table 4): excellent, good, poor, very poor and unfit water for drinking purposes (Sahu and Sikdar, 2008; Ramakrishnaiah et al., 2009). 
Table 1 Physico-chemical parameters of groundwater samples of Hewane areas

\begin{tabular}{|c|c|c|c|c|c|c|c|c|c|c|c|c|c|c|c|c|}
\hline $\begin{array}{l}\text { Sample } \\
\text { code }\end{array}$ & UTME & UTMN & $\begin{array}{c}\text { Elev( } \\
\mathrm{m})\end{array}$ & $\begin{array}{c}\mathrm{EC} \\
\mathrm{dS} / \mathrm{m}\end{array}$ & $\mathrm{pH}$ & $\underset{{ }^{\circ} \mathrm{C}}{\text { Temp }}$ & $\begin{array}{l}\mathrm{Na}^{+} \\
\mathrm{mg} / \mathrm{l}\end{array}$ & $\begin{array}{c}\mathrm{K}^{+} \\
\mathrm{mg} / \mathrm{l}\end{array}$ & $\begin{array}{l}\mathrm{Ca}^{2+} \\
\mathrm{mg} / \mathrm{l}\end{array}$ & $\begin{array}{l}\mathrm{Mg}^{2+} \\
\mathrm{mg} / \mathrm{l}\end{array}$ & $\begin{array}{c}\mathrm{Cl}^{-} \\
\mathrm{mg} / \mathrm{l}\end{array}$ & $\begin{array}{c}\mathrm{HCO}_{3}^{-} \\
\mathrm{mg} / \mathrm{l}\end{array}$ & $\begin{array}{l}\mathrm{SO}_{4}{ }^{2-} \\
\mathrm{mg} / \mathrm{l}\end{array}$ & $\begin{array}{l}\mathrm{TDS} \\
\mathrm{mg} / \mathrm{l}\end{array}$ & $\begin{array}{c}\mathrm{TH} \\
\mathrm{mg} / \mathrm{l}\end{array}$ & $\begin{array}{c}\text { Alkalinity } \\
\mathrm{mg} / \mathrm{l}\end{array}$ \\
\hline GWS_1 & 554398 & 1446044 & 2215 & 1.04 & 7.10 & 21.30 & 26.91 & 2.34 & 112 & 98.4 & 71.0 & 512.4 & 49.49 & 666.66 & 683.44 & 420.00 \\
\hline GWS_2 & 551983 & 1446472 & 2232 & 0.88 & 7.39 & 21.10 & 19.09 & 5.46 & 120 & 96.0 & 213.0 & 353.8 & 60.27 & 564.10 & 693.60 & 290.60 \\
\hline GWS_3 & 552652 & 1447377 & 2074 & 1.10 & 7.19 & 22.00 & 43.93 & 34.32 & 148 & 160.8 & 156.2 & 366.0 & 62.72 & 705.12 & 1029.28 & 300.72 \\
\hline GWS_4 & 552568 & 1447769 & 2087 & 1.50 & 7.37 & 22.30 & 29.90 & 9.36 & 116 & 170.4 & 85.2 & 488.0 & 69.58 & 961.53 & 988.64 & 400.78 \\
\hline GWS_5 & 555107 & 1446263 & 2064 & 3.01 & 6.89 & 23.10 & 36.11 & 51.09 & 412 & 153.6 & 127.8 & 414.8 & 57.82 & 1929.48 & 1768.32 & 340.13 \\
\hline GWS_6 & 553729 & 1448177 & 2061 & 2.11 & 6.84 & 22.60 & 34.04 & 5.46 & 208 & 115.2 & 113.6 & 585.6 & 56.84 & 1352.56 & 992.32 & 480.12 \\
\hline GWS_7 & 553812 & 1448121 & 2025 & 1.04 & 7.25 & 21.40 & 25.07 & 10.14 & 84 & 144.0 & 99.4 & 512.4 & 54.39 & 666.66 & 800.40 & 420.16 \\
\hline GWS_8 & 554000 & 1451777 & 2016 & 1.28 & 7.20 & 21.20 & 28.06 & 22.23 & 120 & 163.2 & 99.4 & 378.2 & 122.50 & 820.51 & 969.12 & 310.51 \\
\hline GWS_9 & 552633 & 1452152 & 1968 & 2.42 & 7.09 & 23.30 & 43.93 & 10.14 & 256 & 211.2 & 170.4 & 378.2 & 79.87 & 1551.28 & 1505.92 & 310.74 \\
\hline GWS_10 & 552601 & 1452117 & 1965 & 2.62 & 7.43 & 23.50 & 36.11 & 30.01 & 412 & 153.6 & 340.8 & 244.0 & 77.91 & 1679.48 & 1659.76 & 200.61 \\
\hline Minimum & & & & 0.88 & 6.84 & 21.10 & 19.09 & 2.34 & 84.00 & 96.00 & 71.00 & 244.00 & 49.49 & 564.10 & 683.44 & 200.61 \\
\hline Maximum & & & & 3.01 & 7.43 & 23.50 & 43.93 & 51.09 & 412.00 & 211.20 & 340.80 & 585.60 & 122.50 & 1929.48 & 1768.32 & 480.12 \\
\hline Average & & & & 1.70 & 7.18 & 22.18 & 32.32 & 18.06 & 198.80 & 146.64 & 147.68 & 423.34 & 69.14 & 1089.74 & 1109.08 & 347.44 \\
\hline $\begin{array}{l}\text { Standard } \\
\text { deviation }\end{array}$ & & & & 0.77 & 0.20 & 0.92 & 8.04 & 15.92 & 123.30 & 35.26 & 80.38 & 100.45 & 21.19 & 495.11 & 394.19 & 82.15 \\
\hline
\end{tabular}

N.B.: TDS=Total Dissolved Solids, TH= Total Hardness, Elev = Elevation and Temp=Temperature

Table 2 WHO Standards, weight (wi) and calculated relative weight (Wi) for each parameter

\begin{tabular}{llll}
\hline Chemical parameters & WHO standards & Weight(wi) & Relative weight(Wi) \\
\hline $\mathrm{Na}^{+}(\mathrm{mg} / \mathrm{l})$ & 200 & 3 & 0.103 \\
$\mathrm{~K}^{+}(\mathrm{mg} / \mathrm{l})$ & 12 & 1 & 0.034 \\
$\mathrm{Ca}^{2+}(\mathrm{mg} / \mathrm{l})$ & 75 & 2 & 0.068 \\
$\mathrm{Mg}^{2+}(\mathrm{mg} / \mathrm{l})$ & 50 & 2 & 0.068 \\
$\mathrm{Cl}^{-}(\mathrm{mg} / \mathrm{l})$ & 250 & 3 & 0.103 \\
$\mathrm{SO}_{4}{ }^{2-}(\mathrm{mg} / \mathrm{l})$ & 250 & 3 & 0.103 \\
$\mathrm{HCO}_{3}{ }^{-}(\mathrm{mg} / \mathrm{l})$ & $120^{*}$ & 2 & 0.068 \\
$\mathrm{pH}^{\mathrm{TDS}}(\mathrm{mg} / \mathrm{l})$ & 8.5 & 3 & 0.103 \\
& 500 & 5 & 0.172 \\
\hline
\end{tabular}

*US Public Health Service values (WHO Standards are not available). 
Table 3 Quality rating (Qi), Sub index of each chemical parameter (SIi), WQI and water classification of each groundwater samples of Hewane areas

\begin{tabular}{|c|c|c|c|c|c|c|c|c|c|c|c|c|c|c|c|c|c|c|c|c|}
\hline \multirow{2}{*}{$\begin{array}{c}\text { Sample } \\
\text { code }\end{array}$} & \multicolumn{2}{|c|}{$\mathrm{Na}^{+}$} & \multicolumn{2}{|c|}{$\mathrm{K}^{+}$} & \multicolumn{2}{|c|}{$\mathrm{Ca}^{2+}$} & \multicolumn{2}{|c|}{$\mathrm{Mg}^{2+}$} & \multicolumn{2}{|c|}{$\mathrm{Cl}^{-}$} & \multicolumn{2}{|c|}{$\mathrm{SO}_{4}{ }^{2-}$} & \multicolumn{2}{|c|}{$\mathrm{HCO}_{3}^{-}$} & \multicolumn{2}{|c|}{$\mathrm{pH}$} & \multicolumn{2}{|c|}{ TDS } & \multirow{2}{*}{ WQI } & \multirow{2}{*}{$\begin{array}{c}\text { WQI } \\
\text { Classificatior }\end{array}$} \\
\hline & Qi & SIi & Qi & SIi & Qi & SIi & Qi & SIi & Qi & SIi & Qi & SIi & Qi & SIi & Qi & SIi & Qi & SIi & & \\
\hline GWS_1 & 13.5 & 1.4 & 19.5 & 0.7 & 149.3 & 10.2 & 196.8 & 13.4 & 28.4 & 2.9 & 20.0 & 2.0 & 427.0 & 29.0 & 83.5 & 8.6 & 133.3 & 22.9 & 91.1 & Good water \\
\hline GWS_2 & 9.5 & 1.0 & 45.5 & 1.5 & 160.0 & 10.9 & 192.0 & 13.1 & 85.2 & 8.8 & 24.1 & 2.5 & 294.8 & 20.0 & 86.9 & 9.0 & 112.8 & 19.4 & 86.1 & Good water \\
\hline GWS_3 & 22.0 & 2.3 & 286.0 & 9.7 & 197.3 & 13.4 & 321.6 & 21.9 & 62.5 & 6.4 & 25.1 & 2.6 & 305.0 & 20.7 & 84.6 & 8.7 & 141.0 & 24.3 & 110.0 & Poor water \\
\hline GWS_4 & 15.0 & 1.5 & 78.0 & 2.7 & 154.7 & 10.5 & 340.8 & 23.2 & 34.1 & 3.5 & 27.8 & 2.9 & 406.7 & 27.7 & 86.7 & 8.9 & 192.3 & 33.1 & 113.9 & Poor water \\
\hline GWS_5 & 18.1 & 1.9 & 425.8 & 14.5 & 549.3 & 37.4 & 307.2 & 20.9 & 51.1 & 5.3 & 23.1 & 2.4 & 345.7 & 23.5 & 81.1 & 8.3 & 385.9 & 66.4 & 180.5 & Poor water \\
\hline GWS_6 & 17.0 & 1.8 & 45.5 & 1.5 & 277.3 & 18.9 & 230.4 & 15.7 & 45.4 & 4.7 & 22.7 & 2.3 & 488.0 & 33.2 & 80.5 & 8.3 & 270.5 & 46.5 & 132.8 & Poor water \\
\hline GWS_7 & 12.5 & 1.3 & 84.5 & 2.9 & 112.0 & 7.6 & 288.0 & 19.6 & 39.8 & 4.1 & 21.8 & 2.2 & 427.0 & 29.0 & 85.3 & 8.8 & 133.3 & 22.9 & 98.5 & Good water \\
\hline GWS_8 & 14.0 & 1.4 & 185.3 & 6.3 & 160.0 & 10.9 & 326.4 & 22.2 & 39.8 & 4.1 & 49.0 & 5.0 & 315.2 & 21.4 & 84.7 & 8.7 & 164.1 & 28.2 & 108.3 & Poor water \\
\hline GWS_9 & 22.0 & 2.3 & 84.5 & 2.9 & 341.3 & 23.2 & 422.4 & 28.7 & 68.2 & 7.0 & 31.9 & 3.3 & 315.2 & 21.4 & 83.4 & 8.6 & 310.3 & 53.4 & 150.8 & Poor water \\
\hline GWS_10 & 18.1 & 1.9 & 250.1 & 8.5 & 549.3 & 37.4 & 307.2 & 20.9 & 136.3 & 14.0 & 31.2 & 3.2 & 203.3 & 13.8 & 87.4 & 9.0 & 335.9 & 57.8 & 166.5 & Poor water \\
\hline
\end{tabular}


Table 4 Classification of computed WQI values for human consumption

\begin{tabular}{ll}
\hline WQI range & Type of water \\
\hline$<50$ & Excellent water \\
$50.1-100$ & Good water \\
$100.1-200$ & Poor water \\
$200.1-300$ & Very poor water \\
$>300.1$ & Unfit for drinking \\
\hline
\end{tabular}

The lower values of WQI show that the water is very clear i.e., it is free of any impurities throughout the study area. Calculation of WQI for individual groundwater sample represented in table 3 and figure 16 varies from 86.1 to 180.5 at groundwater samples GWS_2 and GWS_5, respectively. It is obvious from this classification that on the basis of the WQI, seven groundwater samples from the study area are of poor quality for human consumption except in the groundwater samples GWS_1, GWS_2 and GWS_7 which are of good quality (Sahu and Sikdar, 2008; Ramakrishnaiah et al., 2009). Similar to this study, Khalid (2011) reported that more than $90 \%$ of groundwater samples were found within the poor water class for drinking purposes in groundwater samples of Tikrit and Samarra Cities using water quality index. In contrast to this study, groundwater WQI estimation in Hantebet watershed for drinking purposes was found ranging from 54.41 to 86.24 which means that $100 \%$ of the groundwater samples of the area were found to be good water class Gebrehiwot et al., 2011.

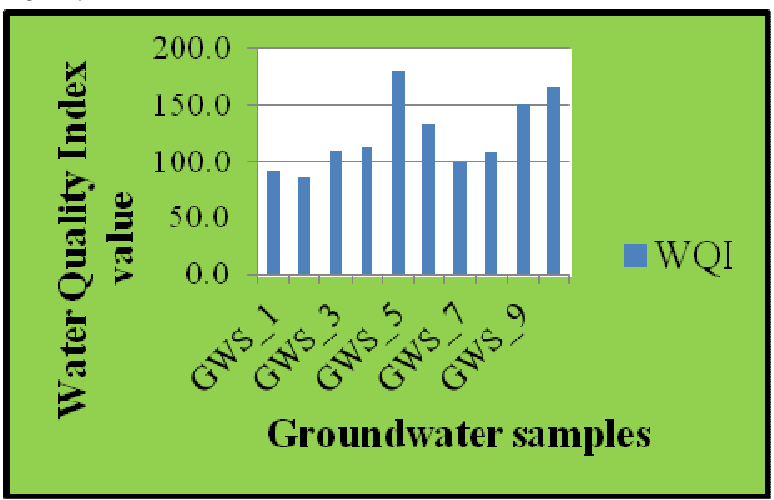

Figure 16 Water quality index classification of Hewane areas

The spatial distribution map of water quality index shows that most of the groundwater samples fall under the poor water class except some areas around samples GWS_1 and GWS_2 (Figure 17).
In this research paper the application of WQI approach to groundwater quality in Hewane areas had the purpose of providing a simple, valid method for expressing the results of several parameters in order to assess the groundwater quality. Assembling different parameters into one single number leads an easy interpretation of index, thus providing an important tool for management purposes (Bordalo et al., 2001).

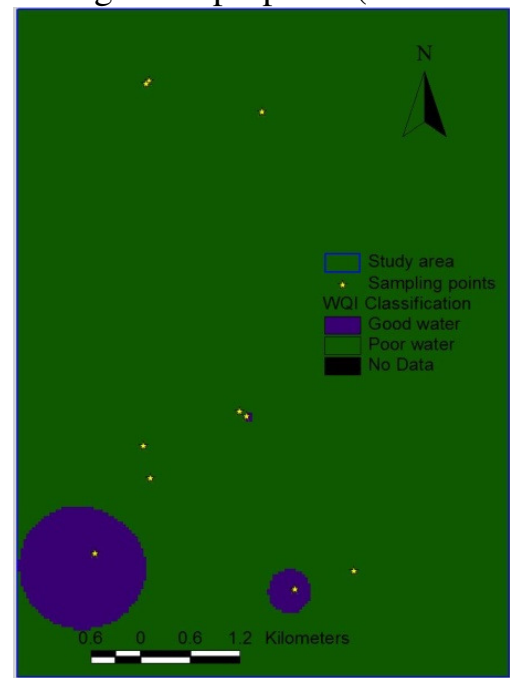

Figure 17 Spatial distribution map of water quality index in Hewane area

\section{Conclusion}

The physico-chemical parameters: $\mathrm{Na}^{+}$, $\mathrm{SO}_{4}{ }^{2-}$ and $\mathrm{pH}$ were found within; $\mathrm{Mg}^{2+}, \mathrm{Cl}^{-}, \mathrm{TH}$ and Alkalinity were found above while parameters $\mathrm{K}^{+}, \mathrm{Ca}^{2+}, \mathrm{HCO}_{3}^{-}, \mathrm{EC}$ and TDS were found partially within and partially above the WHO (2004) standards for drinking purposes.

WQI estimation for each groundwater sample represented in table 3 and figure 16 varied from 86.1 to 180.5 . The estimation showed that $30 \%$ of the groundwater samples were found to be in the good water class and the remaining $70 \%$ were classified under poor water class based on the computed WQI classification scheme.

The spatial distribution maps generated for various physico-chemical parameters using ArcGIS software could be useful for planners, water quality managers and decision makers for initiating groundwater quality development and management in the study area. The spatial distribution map of water quality index shows that most of the groundwater samples fall under the 
poor water class except some areas around samples GWS_1 and GWS_2 (Figure 17).

\section{References}

APHA. (2005). Standard Methods for Examination of Water and Wastewater. Washington DC, USA.

Bordalo, A. A., Nilsumranchit, W. and Chalermwat, K. (2001). Water quality and uses of the Bangpakong River (Eastern Thailand). Wat. Res. 35(15):3635-3642.

Brown, R. M., McCleiland, N. J., Deininger, R. A. and O'Connor, M. F. (1972). A water quality index - crossing the psychological barrier (Jenkis, S.H. ed.) Proc. Int. Conf. on Water Poll. Res., Jerusalem, 6, 787-797.

Challerjee, R., G. Tarafder and S. Paul. (2009). Groundwater quality assessment of Dhanbad district, Jharkhand, India. Bulletin of Engineering Geology and Environment, doi: 10.1007/s10064009-0234-x.

Deutsch, W. J. (1997). Groundwater Geochemistry: Fundamentals and applications to contamination. New York, USA.

Driscoll, F. G. (1986). Groundwater and Wells. Minnesota, USA.

Eaton, A. D., Clesceri, L. S. and Greenberg, A. E. (1998). Standard Method for Examination of Water and Wastewater. Washington DC., USA.

Ferry, L.T., K. Akihiko and M.A. Mohammed Aslam. (2003). A Conceptual Database Design for Hydrology Using GIS. In the Proceedings of Asia Pacific Association of Hydrology and Water Resources, Kyoto, Japan .

Fournier, R. O. (1981). Geothermal Systems: Principles and Case histories. New York, USA.

Gebrehiwot, Abraham Bairu, Tadesse Nata and Jigar Elias. (2011). Application of water quality index to assess suitablity of groundwater quality for drinking purposes in Hantebet watershed, Tigray, Northern Ethiopia. ISABB Journal of Food and Agriculture Science; 1(1), 22 - 30.

Hem, J. D. (1985). Study and interpretation of the chemical characteristics of natural water. U.S.Geol. Surv. Water Supply Paper, 2254, pp 1263.

Horton, R. K., (1965). An index number system for rating water quality. Journal of Water Pollution Control Federation, (37): 300-305.

Kannan, N. and Sabu, J. (2009). Quality of Groundwater in the Shallow Aquifers of a Paddy
Dominated Agricultural River Basin, Kerala, India. World Academy of Science, Engineering and Technology, (52): 475-493.

Khalid H. L. (2011). Evaluation of Groundwater Quality for Drinking Purpose for Tikrit and Samarra Cities using Water Quality Index. Eur. J. Sci. Res., 58(4): 472-481.

Khan, F., T. Husain and A. Lumb. (2003). Water quality evaluation and trend analysis in selected watersheds of the Atlantic Region of Canada. Environmental Monitoring and Assessment, (88): 221-242.

Raghunath, H. M. (2003). Groundwater. New Age International (P) Ltd., New Delhi, pp 344-369.

Ramakrishnaiah, C. R., Sadashivaiah, C. and Ranganna, G. (2009). Assessment of Water Quality Index for the Groundwater in Tumkur Taluk, Karnataka State, India. E Journal of Chemistry, 6(2), 523-530.

Ramesh, R. (2001). Point and Non-point sources of Groundwater Pollution: Case Studies along the East Coast of India. Capital Publishing Company, New Delhi, India, 107p.

Ramesh, K. and L. Elango, (2006). Groundwater Quality Assessment in Tondiar Basin. International Journal of Environmental Pollution, 26(6): 497-504.

Ravikumar, P., R. K. Somashekar and M. Angami. (2010). Hydrochemistry and evaluation of groundwater suitability for irrigation and drinking purposes in the Markandeya River basin, Belgaum District, Karnataka State, India. Environmental Monitoring Assessment, doi: 10.1007/s10661-0101399-2.

Sahu, P. and Sikdar, P. K. (2008). Hydrochemical framework of the aquifer in and around East Kolkata wetlands, West Bengal. India Environ. Geol, (55): 823-835.

Sargaonkar, A. and V. Deshpande, (2003). Development of an overall index of pollution for surfacewater based on a general classification scheme in Indian context. Environmental Monitoring and Assessment, (89): 43-67.

Sawyer, C. N. and McCarty, P. L. (1976). Chemistry of salinity engineers, New York, USA. Srinivasamoorthy, K., Chidambaram, M., Prasanna, M.V., Vasanthavigar, M., John, A. Peter and Anandhan, P. (2008). Identification of major sources controlling Groundwater Chemistry from a hard rock terrain-A case study from Mettur 
taluk, Salem district, Tamilnadu, India. Journal of Earth System Science, 117(1): 49-58.

Tiwari, J. N. and Manzoor, A. (1988). Water quality index for Indian rivers, In: Ecology and Pollution of Indian rivers, (R. K. Trivedy, Ed.), Aashish Publishing House, New Delhi, 271-286.

Todd, D. K. (2001). Groundwater Hydrology, New York, USA.
Todd, D. K. (2005). Groundwater Hydrology, New York, USA.

WHO. (2004). Guidelines for Drinking-Water Quality, Geneva, Switzerland.

WHO. (2008). Guidelines for Drinking-Water Quality, Geneva, Switzerland. 